\title{
RECOVERIES OF MARSH HAWKS BANDED IN SASKATCHEWAN
}

From files of Canadian Wildlife Service

Notes and map by C. Stuart Houston, 863 University Drive, Saskatoon

These 24 recoveries indicate a wider dispersal for Marsh Hawks than for the Red-tailed Hawk and Blackcrowned Night Heron already mapped. A Regina Marsh Hawk went to the state of Washington and a Battleford bird to New Mexico. Recoveries from Georgia and Florida were banded in the eastern part of Saskatchewan. Although the sample is small, one wonders at the absence of recoveries from the middle northern states; is there less shooting there or do Marsh Hawks pass through quickly? Twothirds of the recoveries were direct16 within the year of banding, and the

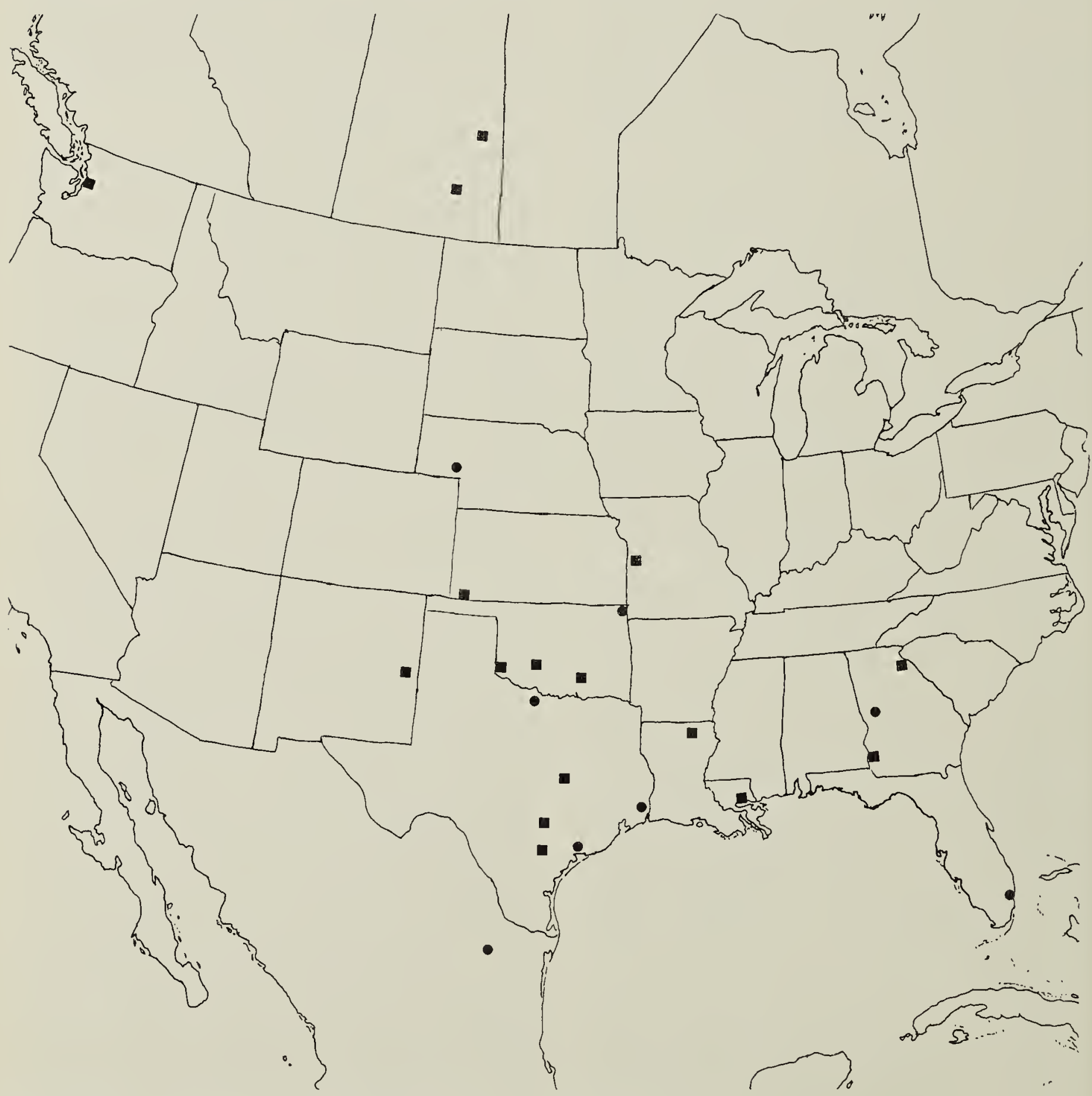

Recoveries of Marsh Hawks banded in Saskatchewan.

Note: Squares represent direct recoveries (same year). Circles represent subsequent years. 
oldest bird was less than six and onehalf years of age when caught in a trap.

Recovery percentages varied widely. R. H. Carter, Jr. had only one recovery from 24 birds banded (under 3\%) and this writer had only two from 82 banded up until the end of 1966 (just over 2\%). On the other hand, the Wotherspoon brothers at Hyas had a phenomenal eight recoveries from 18 banded $(44 \%)$, with half of them from Texas.

Banded by R. H. Carter, Jr., Muscow, Sask. (504-1035) (24 banded) : June 23/29. Shot Dec. 6/29 (direct) Kennedy, Texas (284-0975).

Banded by J. R. Carter, Muscow, Sask. (504-1035) (3 banded) :

June 23/29. Captured Sept. 6/29 (direct) Rolla, Kansas (370-1013). Aug. 8/29. Flew into wire Sept. 11/29 (direct) Ft. Qu'Appelle, Sask. (504-1035).

Banded by Fred G. Bard (504 to $512-1021$ to 1052):

June 28/32. Shot Oct. 13/32 (direct) in Oklahoma (345-0982). June 29/34. Shot Aug. 26/34 (direct) in Washington (475-1222).

July 3/38. Caught in trap before Dec. 6/44 (6 yr.) in Texas (334-0982).

Banded by Bill and Lindsay Wotherspoon, Hyas, Sask. (516-1021) (18 banded): July 9/33. Shot Dec. 26/33 (direct) Archie, Misisouri (383-0942).

July 9/33. Shot Nov. 11/33 (direct) Wynnewood, Okla. (348-0968).

July 29/33. Shot Dec. 20/34 (1 yr.) Beaumont, Texas (300-0940).

July 29/33. Shot Nov. 24/33 (direct) New Orleans, La. (295-0900).

July 29/33. Shot Oct. 21/35 (2 yr.) Edna, Texas (285-0963).

July 1/34. Shot Nov. 15/34 (direct) Temple, Texas (310-0970).

April 25/36. Shot Feb. 6/37 (-1 yr.) Davie, Florida (260-0801).

July 16/44. Shot Oct. 1/44 (direct) in Texas (293-0975).

Banded by F. J. Hartley Fredeen, Macrorie, Sask. (511-1070):

July 8/41. Shot Dec./41 (direct) in Oklahoma (344-0995).

July 8/41. Found dead before Jan. 6/44 (-3 yr.) Nebraska (412-1022).

Banded by Dick Bird, Regina Beach, Sask. (504-1045):

July 10/45. Shot Feb. 10/46 (-1 yr.) in Neuvo Leon, Mexico.

Banded by C. Stuart Houston, Yorkton, Sask. (510-1020 and 512-1015):

June 30/59. Shot before Nov. 13/59 (direct) Monroe, La. (323-0920).

July 17/60. Shot Sept. 21/60 (direct) Martin, Georgia (342-0831).

Banded by Glen A. Fox, Battleford, Sask. (524-1081):

July $9 / 60$. Injured Sept. $1 / 60$ (direct) in New Mexico (342-1033).

July 1/61. Found dead Jan. 22/62 (-1 yr.) in Oklahoma (365-0944).

Banded by Wm. Anaka, Spirit Lake, Sask. (513-1023):

July 18/61. Shot. Nov. 30/61 (direct) in Georgia (312-0845).

July 18/61. Shot Nov. 22/62 (1 yr.) in Georgia (325-0843).

Banded by Walter and Billy Matthews, Nipawin, Sask. (532-1040):

June 30/51. Shot Sept. 15/51 (direct) Somme, Sask. (523-1025).

Note: $513-1023$ mean's $51^{\circ} 30^{\prime}$ North and $102^{\circ} 30^{\prime}$ West.

\section{MIGRANT STARLING}

by Sig Jordheim, White Bear

On June 16, $1967 \mathrm{my}$ children found a starling caught by one toe in a nest hole at a shed. They noticed a band on its leg, but being unable to get at the captive toe, they notified me and I helped them free the bird and get its number. This I sent to the U.S. Fish and Wildlife Service, and the Service has just notified me that the bird was banded at Los Banos, California on January 12,1962 . 